\title{
Morphometric analyses of canine blood microfilariae isolated by the Knott's test enables Dirofilaria immitis and $D$. repens species-specific and Acanthocheilonema (syn. Dipetalonema) genus-specific diagnosis
}

\author{
Johannes Magnis', Susanne Lorentz², Lisa Guardone ${ }^{3}$, Felix Grimm4, Marta Magi ${ }^{3}$, Torsten J Naucke ${ }^{2,5,6}$ \\ and Peter Deplazes ${ }^{4^{*}}$
}

\begin{abstract}
Background: Considering the increasing importance of small animals travel medicine and the spread of filariae with zoonotic potential to non-endemic European areas, routine filarial diagnosis in dogs is becoming important. Dirofilaria immitis, D. repens, Acanthocheilonema dracunculoides and A. reconditum are the most common canine filarial nematodes presenting blood circulating microfilariae ( $\mathrm{mf}$ ) which can be differentiated to species level by the acid phosphatase activity patterns or by PCR. Available data on the size of the $\mathrm{mf}$ vary considerably in the literature. The aim of this study was to validate morphometric criteria for filarial identification in blood samples of dogs after concentration of $\mathrm{mf}$ with the modified Knott's technique.
\end{abstract}

Methods: Morphometric analysis of $10 \mathrm{mf}$ from samples identified to species level by acid phosphatase activity and partially confirmed by PCR were performed with specimens from 377 dogs.

Results: The mean length and width of $D$. immitis $\mathrm{mf}$ from 60 dogs were $301.77 \pm 6.29 \mu \mathrm{m}$ and $6.30 \pm 0.26 \mu \mathrm{m}$, of $D$. repens $\mathrm{mf}$ from 171 dogs $369.44 \pm 10.76 \mu \mathrm{m} 8.87 \pm 0.58 \mu \mathrm{m}$, of $A$. dracunculoides $\mathrm{mf}$ from 133 dogs $259.43 \pm 6.69 \mu \mathrm{m}$ and $5.09 \pm 0.47 \mu \mathrm{m}$ and of $A$. reconditum $\mathrm{mf}$ from 13 dogs $264.83 \pm 5.47 \mu \mathrm{m}$ and $4.63 \pm 0.52 \mu \mathrm{m}$.

For a subset of 30 samples, morphometric analysis was repeated with identical results in two laboratories.

Furthermore, the size of $\mathrm{mf}$ concentrated and fixed by the Knott's technique was shown to be stable over 105 days.

Conclusions: The Knott's test enables to clearly distinguish between D. immitis, D. repens and Acanthocheilonema spp. However, due to the overlapping size ranges of $A$. dracunculoides and A. reconditum, biochemical or molecular methods are required to distinguish these two species.

Keywords: Canine blood microfilariae, Laboratory diagnosis, Size of microfilariae

\section{Background}

In Europe the most common canine filarial species presenting blood circulating microfilariae (mf) are Dirofilaria immitis, D. repens, Acanthocheilonema (syn. Dipetalonema) dracunculoides and A. (syn. Dip.) reconditum [1]. They are transmitted by haematophagous arthropods: Dirofilaria

\footnotetext{
* Correspondence: deplazesp@access.uzh.ch

${ }^{4}$ Institute of Parasitology, University of Zurich, Winterthurerstr. 266a, CH-8057 Zurich, Switzerland

Full list of author information is available at the end of the article
}

spp. by mosquitoes, $A$. reconditum by fleas and lice and $A$. dracunculoides by ticks. $D$. immitis, the aetiological agent of canine heartworm disease, is the most pathogenic species for dogs: adults live in the right side of the heart and in the pulmonary artery, causing pulmonary hypertension and congestive heart failure. Adults of $D$. repens live in the subcutaneous tissue, occasionally causing dermatological problems [2]. A. reconditum and A. dracunculoides live in the peritoneal cavity and adipose tissue and are less pathogenic [3]. However, D. immitis and D. repens are considered 
emerging agents of parasitic zoonoses in Europe with expanding ranges [1], and $A$. reconditum has occasionally been reported as a zoonotic agent [4].

All these species release $\mathrm{mf}$ in the blood of their final hosts, and diagnosis of canine filariosis is mainly based on the detection of circulating mf. Specific identification of these stages is essential for an accurate diagnosis and for choosing the appropriate treatment [5,6]. Data on length and width of $\mathrm{mf}$ reported in the literature vary considerably. The objective of this study was to validate morphometric criteria for species or genus identification of $\mathrm{mf}$ concentrated by the modified Knott's technique, a classical, inexpensive and widely used method.

\section{Methods}

Canine EDTA blood samples containing $\mathrm{mf}(\mathrm{n}=379)$ were collected between 2006 and 2011 by different parasitological laboratories in Europe and sent to Parasitus Ex e.V. in Niederkassel (lab 1). The samples were taken from dogs from Spain (73), Portugal (102), Greece (6), Italy (30), Romania (3), Hungary (141), Bulgaria (1), Turkey (2) and France (1); for 19 samples the dog origin was unknown. Dogs of both sexes and various age groups were sampled; exact age determination was impossible for most dogs due to their unknown history. The modified Knott's technique was applied to concentrate and to detect $\mathrm{mf}$. One $\mathrm{ml}$ of EDTA blood was mixed with $9 \mathrm{ml}$ of $2 \%$ formalin in a $15 \mathrm{ml}$ tube and centrifuged for 5 minutes at $500 \times \mathrm{g}$. The supernatant was poured off, and $2 \times 10 \mu$ l of the sediment was transferred to a slide and covered with a coverslip.

Morphometric analyses of the $\mathrm{mf}$ were conducted with standard diagnostic microscopes equipped with calibrated measuring eyepieces at a final magnification of 200-400 x. Body length and diameter, and the form of the front end and the tail of ten randomly selected $\mathrm{mf}$ were determined. To demonstrate the reliability of the measurements, a subset of 30 samples was repeatedly tested at the Institute of Parasitology, University of Zürich, Switzerland (lab. 2, D. immitis,
$D$. repens and $A$. dracunculoides) and at the Department of Veterinary Science, University of Pisa, Italy (lab. 3, A. reconditum).

To estimate size variations in relation to time, microfilariae in two samples concentrated by the modified Knott's technique were measured repeatedly after intervals of 30 minutes, 2 hours, 6 hours, 24 hours, 7 days, 18 days, 31 days, 45 days, and 105 days (storage of concentrated material at $4^{\circ} \mathrm{C}$ ) by two independent operators in labs 1 and 2 .

All samples had been identified to species level by demonstrating the characteristic acid phosphatase activity patterns [5]. The Leucognost $\mathrm{SP}^{\circledR}$ kit was used according to the manufacturer's recommendations to demonstrate acid phophatase activity patterns in the $\mathrm{mf}$ [6]. The fourteen $A$. reconditum positive samples were additionally stained histochemically [5], as no experience with Leucognost $\mathrm{SP}^{\circledR}$ exists for this species as yet.

Heartworm antigen detection tests were carried out on all blood samples (FASTest ${ }^{\circledR} \mathrm{Hw}$ Ag.; MegaCor or DiroCHEK $^{\circledR}$, Synbiotics). To confirm species identification by acid phosphatase activity, 6 samples with $D$. immitis, 4 with $D$. repens, 7 with $A$. dracunculoides and 14 with $A$. reconditum were investigated by PCR [7], and sequencing confirmed the species identification in all cases.

\section{Results and discussion}

The morphometric results (including standard deviations) are shown in Table 1 and in Figure 1. The mean length of D. immitis mf was $302 \mu \mathrm{m}$, the mean width was $6 \mu \mathrm{m}$, with a conical front end and a straight rear end.

Microfilariae of $D$. repens were $369 \mu \mathrm{m}$ in length and $9 \mu \mathrm{m}$ in width, with a conical front end and curved caudal end. For $A$. dracunculoides, the $\mathrm{mf}$ length was $259 \mu \mathrm{m}$ and the width $5 \mu \mathrm{m}$. The front was round, the end of the tail was straight. Mf of $A$. reconditum had a mean length of $265 \mu \mathrm{m}$ and a mean width of $5 \mu \mathrm{m}$. The front end was blunt, the rear end showed a small hook. In one blood sample, a mixed infection with $D$. immitis

Table 1 Measures $(\mu \mathrm{m})$ of microfilariae determined after fixation with the modified Knott's technique

\begin{tabular}{|c|c|c|c|}
\hline $\begin{array}{l}\text { Microfilariae species identified by histochemical } \\
\text { staining and partially confirmed by } P^{2} R^{a}\end{array}$ & $\begin{array}{l}\text { Total number and origin of } \\
\text { dogs }\end{array}$ & $\begin{array}{l}\text { Mean length } \pm \text { standard } \\
\text { deviation }(\mu \mathrm{m})\end{array}$ & $\begin{array}{l}\text { Mean width } \pm \text { standard } \\
\text { deviation }(\mu \mathrm{m})\end{array}$ \\
\hline Dirofilaria immitis & $\begin{array}{l}60 \text { (GR 1; IT 6; PT 33; ES 16; } \\
\text { TR 2; UO 2) }\end{array}$ & $301.77 \pm 6.29$ & $6.30 \pm 0.26$ \\
\hline Dirofilaria repens & $\begin{array}{l}171 \text { (BG 1; FR 1; GR 5; IT 10; RO } \\
\text { 3; ES 2; HU 141; UO 8) }\end{array}$ & $369.44 \pm 10.76$ & $8.87 \pm 0.58$ \\
\hline Acanthocheilonema dracunculoides & 133 (PT 69; ES 55; UO 9) & $259.43 \pm 6.69$ & $5.09 \pm 0.47$ \\
\hline Acanthocheilonema reconditum & 13 (IT 13) & $264.83 \pm 5.47$ & $4.63 \pm 0.52$ \\
\hline
\end{tabular}

Mean length and mean width $(\mu \mathrm{m})$ of microfilariae determined after fixation with the modified Knott's technique of confirmed single filarial infections in 377 dogs.

IT, Italy; ES, Spain; GR, Greece; PT, Portugal; RO, Romania; HU, Hungary; BG, Bulgaria; TR, Turkey; FR, France; Unknown Origin: UO.

a PCR confirmation for 6 samples positive for D. immitis, 4 for D. repens, 7 for A. dracunculoides and 6 for A. reconditum infections. 


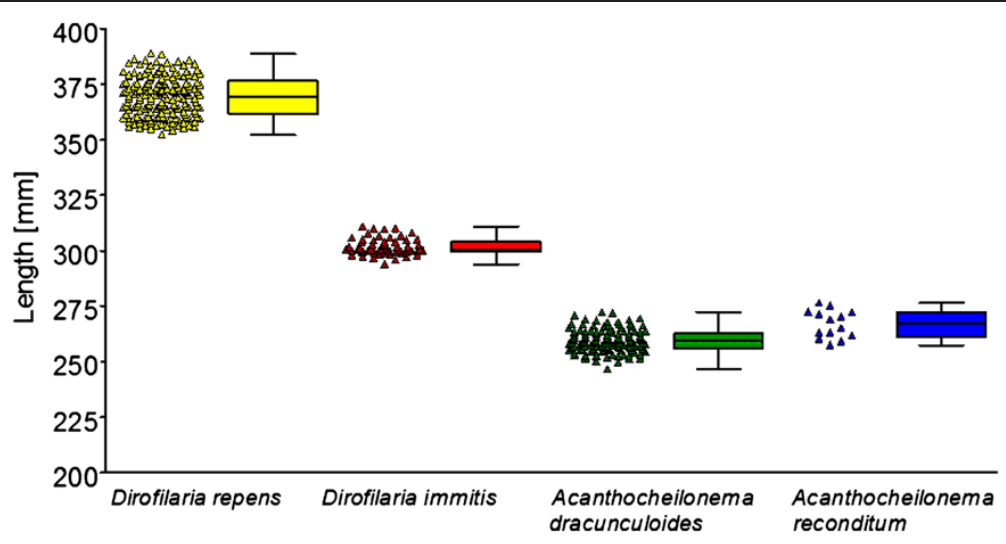

Figure 1 Mean length $(\mu \mathrm{m})$ of microfilariae determined after fixation with the modified Knott's technique. Measurements were conducted for 377 dogs with confirmed filarial infections (histochemical staining and PCR in part of the cases); each indicator corresponds to a dog sample, for which 10 microfilariae were measured.

and $A$. dracunculoides was detected. In this case, circulating $D$. immitis-antigens could be demonstrated and, after staining with the Leucognost $\mathrm{SP}^{\circledR}$ kit, most of the $\mathrm{mf}$ were identified as $A$. dracunculoides and a lower number as D. immitis. However, only A. dracunculoidesDNA was detected by PCR in this sample. Another dog was positive for $D$. repens and $A$. reconditum; in this case histochemical staining and PCR identified both species. These two samples were excluded from the morphometric analyses (Table 1).

No significant differences of the morphometric data were observed for the $\mathrm{mf}$ in the 30 samples retested in labs 2 and 3 (data not shown). Furthermore, no significant size differences were observed over time (30 minutes to 105 days) in formalin fixed samples (Figure 2): the stability of fixed microfilariae is of practical importance as it allows transport of samples to a specialized laboratory if needed.

In accordance with the expected acidic phosphatase activity patterns $[5,8,9], D$. immitis $\mathrm{mf}$ displayed two spots (excretory and anal pores), D. repens one spot (anal pore) and A. dracunculoides three areas of enzymatic activity (anal pore, internal body, excretory pore) when stained with the Leucognost $\mathrm{SP}^{\circledR}$ kit. Using this kit, acid phosphatase activity could not be demonstrated in any of the A. reconditum $\mathrm{mf}$. A technical failure of the kit could be excluded since $D$. immitis specimens were included in the staining runs and always gave results as expected. When stained histochemically [5], $A$. reconditum $\mathrm{mf}$ showed a diffuse light red pattern. The

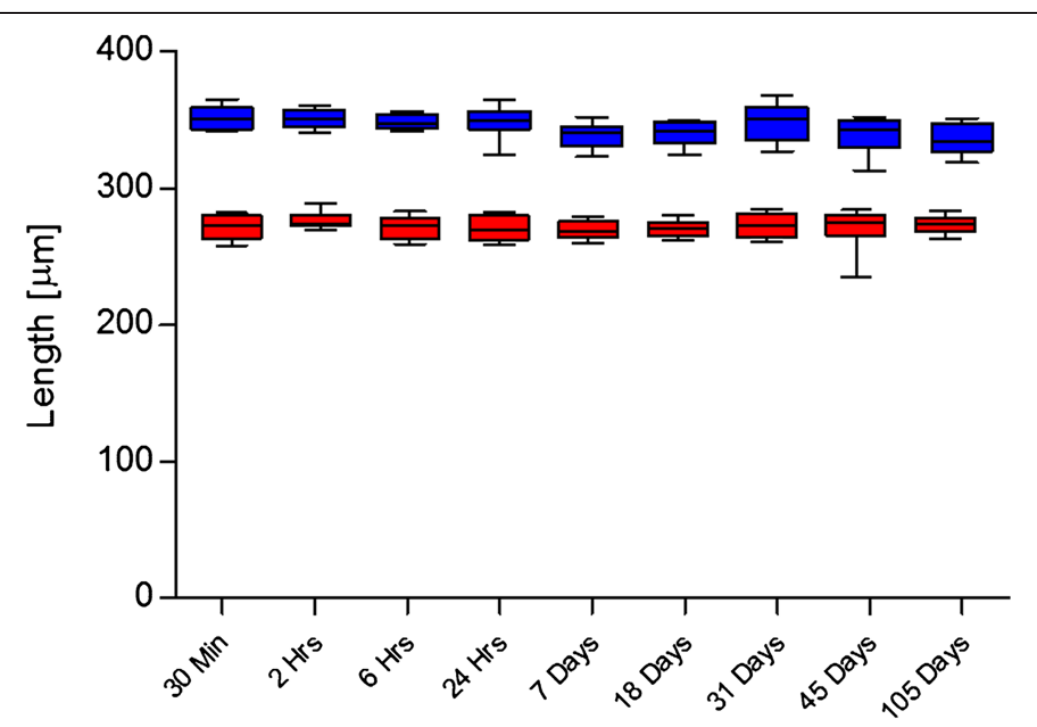

Figure 2 Mean length of Dirofilaria repens and Acanthocheilonema dracunculoides microfilariae over time. Length of microfilariae ( $\mathrm{n}=10$ ) of Dirofilaria repens (blue, above) and Acanthocheilonema dracunculoides (red, below) after formalin fixation with the modified Knott's technique over a period of 105 days. 
reason why $A$. reconditum $\mathrm{mf}$ were not stained by Leucognost $\mathrm{SP}^{\circledR}$ is not clear, and more experience with this kit applied to $A$. reconditum is needed. Circulating $D$. immitis antigens could be demonstrated in all samples containing $\mathrm{mf}$ of this species. All other samples, except for one case where $A$. dracunculoides $\mathrm{mf}$ were detected, were negative with this test. PCR [7] and sequencing confirmed the species identification in all cases.

The measures found in our study agree well with the results of comparable studies $[5,10,11]$. In a survey of 351 dogs, $\mathrm{mf}$ of $D$. immitis were reported to be $311.3 \pm 9.5 \mu \mathrm{m}$ long and $5.96 \pm 0.15 \mu \mathrm{m}$ wide, D. repens $366.2 \pm 12.1 \times$ $6.40 \pm 0.3$ and $A$. reconditum $265.2 \pm 10.1 \times 5.01 \pm 0.49$ [10]. The latter species has recently been reported with a mean length of $273.1 \pm 9.4$ and a mean width of $5.4 \pm 0.2$ [11]. In another study, the length of $D$. repens $\mathrm{mf}$ isolated by the modified Knott's technique from blood samples of 8 Romanian dogs had been reported to vary between $300.3 \pm 38.0$ and $342.8 \pm 18.1$ [12]. The obvious difference to our measurements cannot be fully explained. However, the authors solely used morphological criteria for species identification without confirmation by additional histochemical or molecular methods. Regarding A. dracunculoides, our results correspond to a study [9] in which the mean size of 150 microfilariae from 14 positive dogs was $256.5 \pm$ $9.2 \times 5.5 \pm 0.5$. The microfilariae of $A$. dracuculoides are slightly shorter than $A$. reconditum, as reported in dogs in this study (Table 1) and in [13] as well as in foxes [14,15].

In recent publications [16,17] or guidelines [18], broader size ranges are reported. This could partly be due to the influence of examination methods. Air-drying and methanol fixation as used for Giemsa staining will affect size in a different way than the formalin treatment of the Knott's technique. In a recent study, the mean length of Giemsa-stained D. immitis and D. repens $\mathrm{mf}$ in thin blood films [19] was shown to be significantly shorter than after applying the Knott's test.

Other species of canine filariae, such as Cercopithifilaria spp., present microfilariae in the dermis, thus they do not represent a real issue in the differential diagnosis of $\mathrm{mf}$ circulating in blood. Furthermore, the length of Cercopithifilaria spp. $\mathrm{mf}$ significantly differs from the length of Dirofilaria and Acanthocheilonema spp. mf [16].

The Knott's technique has several advantages. It is easy to perform, rapid and inexpensive, it conserves $\mathrm{mf}$ morphology and size, and it enhances the sensitivity of mf detection in blood samples. Courtney and Zeng [20] showed that only in $80.9 \%$ of the samples in which $D$. immitis $\mathrm{mf}$ had been detected by the Knott's test, the parasites could also be found in direct smears and that the sensitivity of the direct smear was especially low in samples with less than $10 \mathrm{mf}$ per $\mathrm{ml}$. This is of particular relevance for $A$. dracunculoides and $A$. reconditum $\mathrm{mf}$, since the average number of $\mathrm{mf} / \mathrm{ml}$ is usually low in these species $[10,11,13]$.

Considering the recent spread of canine filarial infections, particularly of $D$. repens, from southern to more northern and eastern European areas [21,22], the increased importance of canine travel medicine due to tourism with pets and the import of dogs from eastern and southern endemic European countries to central Europe [23], the diagnosis of filarial infections in dogs is becoming more and more important.

\section{Conclusion}

The morphometric analysis proved to be a very useful, quick and inexpensive diagnostic tool and it represents the first step in the diagnosis of filarial infections. However, the discrimination between different species can be challenging in cases of mixed infections [17,24] or in cases with low parasitaemia. In these cases, as well as in cases where discrimination between Acanthocheilonema spp. is required, molecular methods (e. g. PCR [7,25]) or histochemical staining $[5,6]$ are required.

\section{Competing interests}

The authors declare that they have no competing interests.

\section{Authors' contributions}

JM participated in the design of the study and coordinated the sample collection; this paper represents his doctoral thesis. SL participated with the laboratory analyses. LG contributed with the sample collection and preparation of the manuscript. FG participated with the laboratory analyses and preparation of the manuscript. MM contributed with the sample collection and drafted the manuscript. TJN enabled the sample collection and participated with the design of the study. PD conceived the study and implemented the draft of the manuscript. All authors read and approved the final version of the manuscript.

\section{Author details}

${ }^{1}$ Kleintierklinik in Iffezheim, An der Rennbahn 16a, 76473 Iffezheim, Germany. ${ }^{2}$ Parasitus Ex e.V, Vollbergstrasse 37, 53859 Niederkassel, Germany.

${ }^{3}$ Department of Veterinary Science, University of Pisa, viale delle Piagge 2, 56124 Pisa, Italy. ${ }^{4}$ Institute of Parasitology, University of Zurich,

Winterthurerstr. 266a, CH-8057 Zurich, Switzerland. ${ }^{5}$ Department of Zoology, Division of Parasitology, University of Hohenheim, 70599 Stuttgart, Germany. ${ }^{6}$ Laboklin GmbH \& Co. KG, Steubenstraße 4, 97688 Bad Kissingen, Germany.

Received: 21 January 2013 Accepted: 19 February 2013 Published: 25 February 2013

\section{References}

1. Genchi C, Kramer LH, Rivasi F: Dirofilarial infections in Europe. Vector Borne Zoonotic Dis 2011, 10:1307-1317.

2. Bredal WP, Gjerde B, Eberhard ML, Aleksandersen M, Wilhelmsen DK, Mansfield LS: Adult Dirofilaria repens in a subcutaneous granuloma on the chest of a dog. J Small Anim Pract 1998, 39:595-597.

3. Lindemann BA, Evans TL, McCall JW: Clinical responses of dogs to experimentally induced Dipetalonema reconditum infection. Am J Vet Res 1983, 44:2170-2172.

4. Huynh T, Thean J, Maini R: Dipetalonema reconditum in the human eye. $\mathrm{Br}$ J Ophthalmol 2001, 85:1391-1392

5. Chalifoux L, Hunt RD: Histochemical differentiation of Dirofilaria immitis and Dipetalonema reconditum. J Am Vet Med Assoc 1971, 5:601-605.

6. Peribanez MA, Lucientes J, Arce S, Morales M, Castillo JA, Gracia MJ: Histochemical differentiation of Dirofilaria immitis, Dirofilaria repens and 
Acanthocheilonema dracunculoides microfilariae by staining with a commercial kit, Leucognost-SP ${ }^{\circledR}$. Vet Parasitol 2001, 102:173-175.

7. Rishniw M, Barr SC, Simpson KW, Frongillo MF, Franz M, Dominguez Alpizar JL: Discrimination between six species of canine microfilariae by a single polymerase chain reaction. Vet Parasitol 2006, 135:303-314.

8. Balbo T, Abate O: Histochemical differentiation of microfilariae of Dirofilaria immitis, Dirofilaria repens and Dipetalonema sp. Parassitologia 1972, 14:240-244.

9. Ortega-Mora LM, Gomez-Bautista M, Rojo-Vazquez FA: The acid phosphatase activity and the morphological characteristic of Dipetalonema dracunculoides (Cobbold, 1870) microfilariae. Vet Parasitol 1989, 33:187-190.

10. Cringoli G, Rinaldi L, Veneziano V, Capelli G: A prevalence survey and risk analysis of filariasis in dogs from the Mt. Vesuvius area of southern Italy. Vet Parasitol 2001, 102:243-252.

11. Brianti E, Gaglio G, Napoli E, Giannetto S, Dantas-Torres F, Bain O, Otranto D: New insights into the ecology and biology of Acanthocheilonema reconditum (Grassi, 1889) causing canine subcutaneous filariosis. Parasitology 2012, 139:530-536.

12. Ciocan $R$, Dărăbuş $G$, Igna $V:$ Morphometric study of microfilariae of Dirofilaria spp. on dogs. Bull UASVM Vet Med 2010, 67:45-49.

13. Giannetto S, Poglayen G, Gaglio G, Brianti E, Ferlazzo M, Giudice E: Dipetalonema dracunculoides (Nematoda: Onchocercidae): first report for Italian dogs. Parasite 2003, 10:188.

14. Marconcini A, Magi M, Macchioni G, Sassetti M: Filariosis in foxes in Italy. Vet Res Commun 1996, 20:316-319.

15. Magi M, Macchioni F, Dell'Omodarme M, Prati MC, Calderini P, Gabrielli S, Iori A, Cancrini G: Endoparasites of red fox (Vulpes vulpes) in central Italy. J Wild Dis 2009, 45:881-885.

16. Otranto D, Brianti E, Dantas-Torres F, Weigl S, Latrofa MS, Gaglio G, Cauquil L, Giannetto S, Bain O: Morphological and molecular data on the dermal microfilariae of a species of Cercopithifilaria from a dog in Sicily. Vet Parasitol 2011, 182:221-229.

17. Traversa D, Di Cesare A, Conboy G: Canine and feline cardiopulmonary parasitic nematodes in Europe: emerging and underestimated. Parasit Vectors 2010, 3:62

18. ESCCAP Guideline 5: Control of Vector-Borne Diseases in Dogs and Cats. Secondth edition. 2012. http://www.esccap.org/uploads/file/ESCCAP\% 20Guidelines\%20GL5\%2001Oct2012.pdf.

19. Liotta JL, Sandhu GK, Rishniw M, Bowman DD: Differentiation of the microfilariae of Dirofilaria immitis and Dirofilaria repens in stained blood films. J Parasitol. in press.

20. Courtney $\mathrm{CH}$, Zeng QY: Relationship between microfilaria count and sensitivity of the direct smear for diagnosis of canine dirofilariosis. Vet Parasitol 2001, 94:199-204.

21. Genchi C, Rinaldi L, Mortarino M, Genchi M, Cringoli G: Climate and Dirofilaria infection in Europe. Vet Parasitol 2009, 163:286-292.

22. Kramer L, Kartashev W, Grandi G, Morchón R, Nagornii SA, Karanis P, Simón F: Human subcutaneous dirofilariasis in Russia. Emerg Infect Dis 2007, 13:150-152

23. Deplazes P, Staebler S, Gottstein B: Travel medicine of parasitic diseases in the dog. Schweiz Arch Tierheilkd 2006, 148:447-461.

24. Magi M, Guardone L, Prati MC, Tozzini G, Torracca B, Monni G, Macchioni F: Canine filarial infections in Tuscany, central Italy. J Helminthol 2012, 86:113-116.

25. Latrofa MS, Weigl S, Dantas-Torres F, Annoscia G, Traversa D, Brianti E, Otranto D: A multiplex PCR for the simultaneous detection of species of filarioids infesting dogs. Acta Trop 2012, 122:150-154.

doi:10.1186/1756-3305-6-48

Cite this article as: Magnis et al:: Morphometric analyses of canine blood microfilariae isolated by the Knott's test enables Dirofilaria immitis and $D$. repens species-specific and Acanthocheilonema (syn.

Dipetalonema) genus-specific diagnosis. Parasites \& Vectors 2013 6:48.

\section{Submit your next manuscript to BioMed Central and take full advantage of:}

- Convenient online submission

- Thorough peer review

- No space constraints or color figure charges

- Immediate publication on acceptance

- Inclusion in PubMed, CAS, Scopus and Google Scholar

- Research which is freely available for redistribution 